\title{
MORPHOLOGICAL ANALYSIS OF VARIATIONS OF SPLEEN
}

\section{Ganesh Trimbak Waghmode ${ }^{1}$, Satishkumar Sukhanand Porwal ${ }^{2}$, Pavankumar Bharat Shinde ${ }^{3}$, Uma Trimbak Waghmode ${ }^{4}$.}

${ }^{* 1}$ Department of Anatomy, Navodaya Medical College, Raichur, Karnatka, India.

${ }^{2}$ S.R.T.R. Govt. Medical College, Ambajogai, Maharashtra, India.

${ }^{3}$ Primary health centre Sangeli, Tal Sawantwadi Dist Sindhudurg, Maharashtra, India.

${ }^{4}$ Rural hospital Mohol, Solapur Dist., Maharashtra, India.

\section{ABSTRACT}

Background: Spleen is encapsulated vascular and lymphoid organ. Clinically study of spleen is significant in immunological and haematological disorders. Context and purpose of the study is to study morphological variations of spleen and to compare them with previous studies.

Materials and Methods: Present study carried out with 74 spleens at the Department of Anatomy, Navodaya Medical College, Raichur, Karnatka, India, furthermore we observed for various morphological features.

Results: Out of 74 spleens 11 spleens were triangular, 41 spleens were tetrahedral and 22 spleens were wedge shaped. The mean length was $11 \mathrm{~cm}$, the mean breadth was $7.1 \mathrm{~cm}$, the mean width was $5.45 \mathrm{~cm}$, the mean weight was $141.77 \mathrm{gms}$ and the mean volume was $140.45 \mathrm{~cm}^{3}$.

Conclusion: 74 normal spleens were studied with shapes, lengths, breadths, widths, weights and volumes were analysed. Present study will help radiologists, physicians and surgeons in diagnosing disorders of spleen.

KEY WORDS: Volume of spleen, Shape of spleen, Disorders of spleen, Lymphoid organ.

Address for Correspondence: Dr. Ganesh Trimbak Waghmode, Navodaya Medical College, Raichur, Karnatka, India. Pin 584101 E-Mail: gw1726@gmail.com

\begin{tabular}{|c|c|c|}
\hline \multicolumn{3}{|c|}{ Access this Article online } \\
\hline \multirow{2}{*}{$\begin{array}{l}\text { Quick Response code } \\
\text { DOI: } 10.16965 / \text { ijar.2017.143 }\end{array}$} & \multicolumn{2}{|c|}{$\begin{array}{l}\text { Web site: International Journal of Anatomy and Research } \\
\qquad \text { ISSN 2321-4287 } \\
\text { www.ijmhr.org/ijar.htm }\end{array}$} \\
\hline & $\begin{array}{l}\text { Received: } 10 \text { Feb } 2017 \\
\text { Peer Review: } 10 \text { Feb } 2017 \\
\text { Revised: } 21 \text { Feb } 2017\end{array}$ & $\begin{array}{l}\text { Accepted: } 03 \text { Apr } 2017 \\
\text { Published (O): } 30 \text { Apr } 2017 \\
\text { Published (P): } 30 \text { Apr } 2017\end{array}$ \\
\hline
\end{tabular}

\section{INTRODUCTION}

Spleen is secondary lymphoid organ as it is the site of maturation of lymphocyte and their activation and initiation of an immune response, spleen is organ of haemopoeisis before bonemarow development [1]. The spleen is the grave yard of dead red blood cells as the spleen is the site of red blood cell destruction [2]. The spleen has third highest blood perfusion rate [3]. The spleen is called as melancholy as ancient Greece scientist thought that the spleen was the source of black bile [4].
The spleen is not essential for life as removal of spleen does not leads to sudden death [5]. Dimensions and functions of spleen were discovered in $20^{\text {th }}$ century [6]. It may become haemopoietic in pathological conditions. It is situated between diaphragm and fundus of stomach in the left hypochondium and partly in the epigastrium.The spleen has two surfaces diaphragmatic and visceral [1]. Spleen develops in dorsal mesogastrium. The process of formation of spleen occurs at several adjoining areas which fuse to form lobulated 
spleen Early lobulated character of the spleen disappears but notches at upper border remains [7].

Spleen has visceral and diaphragmatic surfaces, anterior and posterior extremities and inferior and superior borders [1]. Accessory spleens may be present in $4.50 \%$ cases, in the form of roundish nodules at the hilum of the spleen [8].

Visceral surface presents gastric, renal colic and pancreatic impressions Diaphragmatic surface is smooth and convex, directed upwards, backwards and to the left. Superior border separating the gastric impression from the diaphragmatic surface is thin, convex and presents one or two notches close to the lateral end. Inferior border separates the renal impression from diaphragmatic surface and extends obliquely coinciding with the lower border of the left 11 rib.

Posterior extremity or medial end is blunt and rounded, directed upwards backwards and medially towards vertebral column. Anterior extremity or lateral end is broad and represented by a border, which extends between superior and inferior borders. It is directed downwards, forwards and to the left Anterior basal angle is the junction of the superior border and lateral end and it represents the most forward projecting part of spleen. Posterior basal angle is the junction of the inferior border and lateral end of spleen [9].

Spleenomegaly is important diagnostic sign in malaria, kalaazar, inflammatory and degenerative disorders [10]. In spleenomegaly, the anterior border, anterior part of diaphragmatic surface and notched superior border may become clearly palpable below the left costal margin [11].

\section{MATERIALS AND METHODS}

74 spleens collected from department of anatomy R.G.I.M.S. Srikakulam, NRI.I.M.S. Visakhapatnam and N.M.C. Raichur. Intact normal human cadaveric spleens were selected only 7 spleens from female cadaver were available. dissection was done with standard method of cadaveric dissection 9 measurement were calculated by Vernier calliper and electric weighing machine.

Length $=$ greatest distance between two poles
Breadth $=$ greatest distance between two points at superior and inferior Borders

Width $=$ greatest width

Volume [12] $=(0.36 \mathrm{X}$ Length X Breadth X Width) $+28$

Different shapes were observed. The obtained data analysed and compared with previous studies.

\section{RESULTS}

In all 74 spleens two poles anterior and posterior, two borders superior and inferior and two surfaces diaphragmatic and visceral were observed.

Gastric, renal, colic and pancreatic impressions were seen at the visceral surfaces of all 74 spleens.

Out of 74 spleens 11 spleens were triangular shaped, 41 spleens were tetrahedral shaped and 22 spleens were wedge shaped oval and irregular shaped spleens were not seen in present study.

Fig. 1: Showing the triangular spleen.

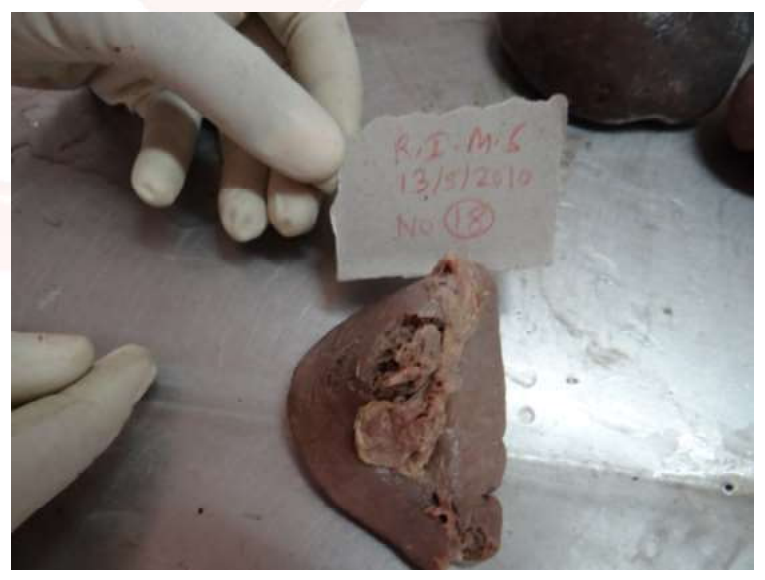

Fig. 2: Showing the wedge shaped spleen.

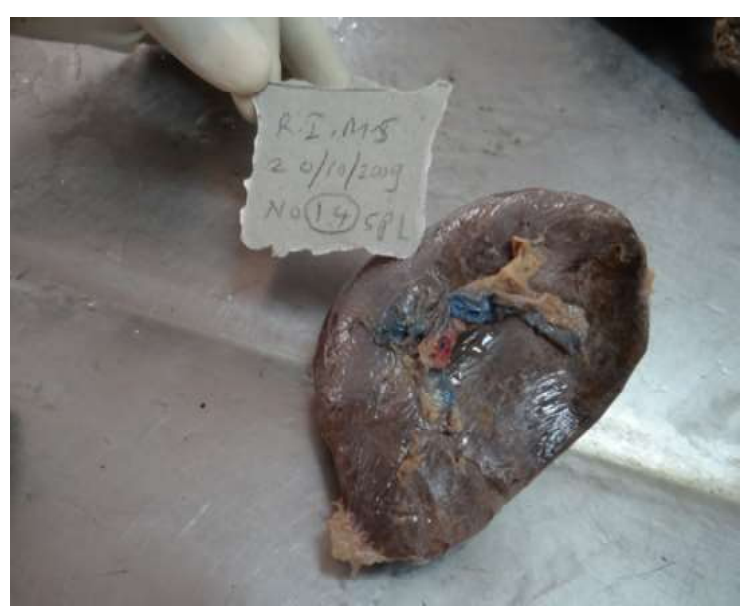


Fig. 3: Showing the tetrahedral spleen.

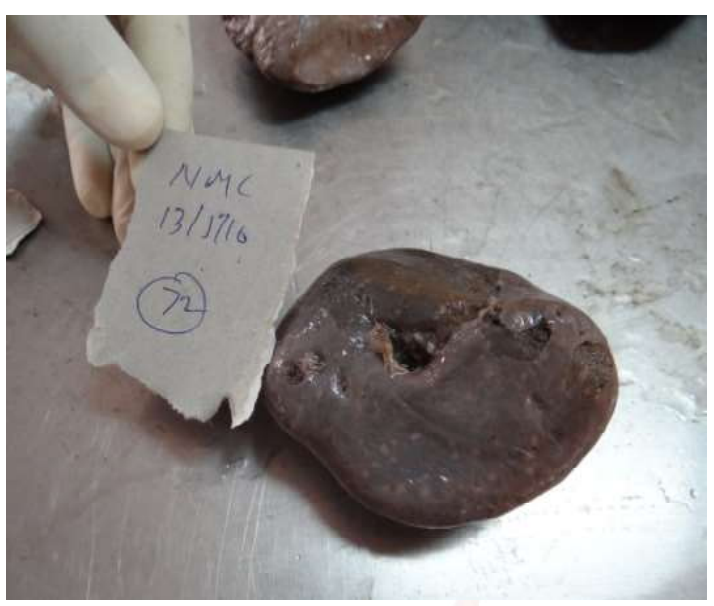

Fig. 4: Showing the measurement of the Splenic Morphometric parameters.

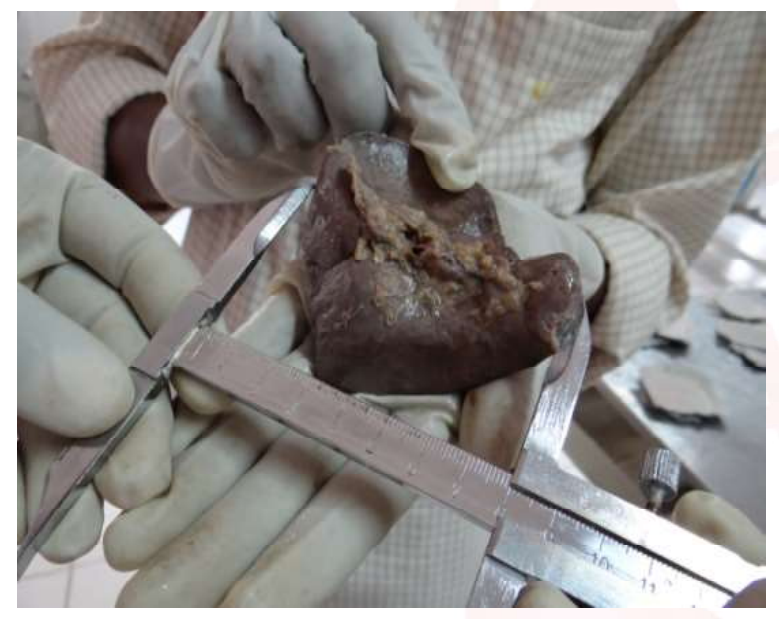

In Table 1 in present study weight of spleen varied between 56gms. - 344gm. 65 spleens $(87.83 \%)$ varied between $100 \mathrm{gms}$. to $200 \mathrm{gms}$. Only 2 spleens varied between $250 \mathrm{gms}$ to $350 \mathrm{gms}$. Five spleens are having less weight varied between $50 \mathrm{gms}$ to $99 \mathrm{gms}$. Average weight of spleen was $141.77 \mathrm{gms}$.

Table 1: Weights of spleen in present study.

\begin{tabular}{|c|c|c|}
\hline Sr. No. & $\begin{array}{c}\text { Weight of spleen in } \\
\text { grams }\end{array}$ & $\begin{array}{c}\text { Number of } \\
\text { spleens }\end{array}$ \\
\hline 1 & 50gms to 99gms & 5 \\
\hline 2 & 100gms to 149gms & 42 \\
\hline 3 & 150gms to 199gms & 23 \\
\hline 4 & $200 \mathrm{gms}$ to 249gms & 2 \\
\hline 5 & $250 \mathrm{gms}$ to 299gms & 1 \\
\hline 6 & 300gms to 350gms & 1 \\
\hline
\end{tabular}

In Table 2 in present study length of spleens varied between $72 \mathrm{~mm}$ to $137 \mathrm{~mm} 62$ spleens their lengths varied between $82 \mathrm{~mm}$ to $118 \mathrm{~mm}$. Only four spleen varied between lengths $120 \mathrm{~mm}$ to $139 \mathrm{~mm}$. Eight spleens have less length varied between $70 \mathrm{~mm}$ to $79 \mathrm{~mm}$ Average length was $97.89 \mathrm{~mm}$.

Table 2: Lengths of spleens in present study.

\begin{tabular}{|c|c|c|}
\hline Sr. No & $\begin{array}{c}\text { Length of spleen in } \\
\text { millimetres }\end{array}$ & $\begin{array}{c}\text { Number of } \\
\text { spleens }\end{array}$ \\
\hline 1 & $70 \mathrm{~mm}$ to $79 \mathrm{~mm}$ & 8 \\
\hline 2 & $80 \mathrm{~mm}$ to $89 \mathrm{~mm}$ & 14 \\
\hline 3 & $90 \mathrm{~mm}$ to $99 \mathrm{~mm}$ & 18 \\
\hline 4 & $100 \mathrm{~mm}$ to $109 \mathrm{~mm}$ & 17 \\
\hline 5 & $110 \mathrm{~mm}$ to $119 \mathrm{~mm}$ & 13 \\
\hline 6 & $120 \mathrm{~mm}$ to $129 \mathrm{~mm}$ & 3 \\
\hline 7 & $130 \mathrm{~mm}$ to $139 \mathrm{~mm}$ & 1 \\
\hline
\end{tabular}

In Table 3 in present study breadth of spleens varied between $38 \mathrm{~mm}$ to $92 \mathrm{~mm} 72$ spleens varied between $41 \mathrm{~mm}$ to $79 \mathrm{~mm}$. Only seven spleens varied between breadth $70 \mathrm{~mm}$ to $89 \mathrm{~mm}$. Eight spleens have less breadth varied between $30 \mathrm{~mm}$ to $49 \mathrm{~mm}$. Average breadth was $59.58 \mathrm{~mm}$.

Table 3: Breadth of spleens in present study.

\begin{tabular}{|c|c|c|}
\hline Sr. No. & Breadth in millimetre & $\begin{array}{c}\text { Number of } \\
\text { spleens }\end{array}$ \\
\hline 1 & $30 \mathrm{~mm}$ to $39 \mathrm{~mm}$ & 1 \\
\hline 2 & $40 \mathrm{~mm}$ to $49 \mathrm{~mm}$ & 7 \\
\hline 3 & $50 \mathrm{~mm}$ to $59 \mathrm{~mm}$ & 33 \\
\hline 4 & $60 \mathrm{~mm}$ to $69 \mathrm{~mm}$ & 25 \\
\hline 5 & $70 \mathrm{~mm}$ to $79 \mathrm{~mm}$ & 6 \\
\hline 6 & $80 \mathrm{~mm}$ to $89 \mathrm{~mm}$ & 1 \\
\hline 7 & $90 \mathrm{~mm}$ to $99 \mathrm{~mm}$ & 1 \\
\hline
\end{tabular}

In Table 4 in present study width of spleen varied between $11 \mathrm{~mm}$ to $74 \mathrm{~mm}$. 71 spleens were varied between $31 \mathrm{~mm}$ to $69 \mathrm{~mm}$. Average width was $49.78 \mathrm{~mm}$

Table 4: Widths of spleen in present study.

\begin{tabular}{|c|c|c|}
\hline Sr.No. & Width in millimetre & $\begin{array}{c}\text { Number of } \\
\text { spleens }\end{array}$ \\
\hline 1 & $20 \mathrm{~mm}$ to $29 \mathrm{~mm}$ & 2 \\
\hline 2 & $30 \mathrm{~mm}$ to $39 \mathrm{~mm}$ & 11 \\
\hline 3 & $40 \mathrm{~mm}$ to $49 \mathrm{~mm}$ & 23 \\
\hline 4 & $50 \mathrm{~mm}$ to $59 \mathrm{~mm}$ & 29 \\
\hline 5 & $60 \mathrm{~mm}$ to $69 \mathrm{~mm}$ & 8 \\
\hline 6 & $70 \mathrm{~mm}$ to $79 \mathrm{~mm}$ & 1 \\
\hline
\end{tabular}

In Table 5 in present study notches of spleens varied between 0 to 3 notches. 57 spleens have only one notch. Four spleen were present without notch. Two notches were present in 12 spleens. Only one spleen was present with three notches. 
Table 5: Number of notches of spleen in present study.

\begin{tabular}{|c|c|c|}
\hline Sr.No. & $\begin{array}{c}\text { Number of } \\
\text { notches }\end{array}$ & $\begin{array}{c}\text { Number of } \\
\text { spleens }\end{array}$ \\
\hline 1 & 0 & $4(5.41 \%)$ \\
\hline 2 & 1 & $57(77.03 \%)$ \\
\hline 3 & 2 & $12(16.22 \%)$ \\
\hline 4 & 3 & $1(1.36 \%)$ \\
\hline
\end{tabular}

In Table 6 in present study volume of spleen were measured in unit cubic centimetre. volume of spleen were varied between $55.57 \mathrm{~cm}^{3}$ to $363.77 \mathrm{~cm}^{3}$. Only seven spleens were present with largest volume varied between volume $200 \mathrm{~cm}^{3}$ to $400 \mathrm{~cm}^{3} .15$ spleens were having less volume varied between volume $50 \mathrm{~cm}^{3}$ to to $99 \mathrm{~cm}^{3}$. Average volume was $140.45 \mathrm{~cm}^{3}$

Table 6: volumes of spleen in present study.

\begin{tabular}{|c|c|c|}
\hline Sr.No. & $\begin{array}{c}\text { Volume of spleen in } \\
\text { cm3 }\end{array}$ & $\begin{array}{c}\text { Number of } \\
\text { spleens }\end{array}$ \\
\hline 1 & 50 to 99 & 15 \\
\hline 2 & 100 to 149 & 33 \\
\hline 3 & 150 to 199 & 19 \\
\hline 4 & 200 to 249 & 5 \\
\hline 5 & 250 to 299 & 1 \\
\hline 6 & 300 to 349 & 0 \\
\hline 7 & 350 to 400 & 1 \\
\hline
\end{tabular}

\section{DISCUSSION}

According to Sir Alfred Cuschier spleen varies in shape and three morphological types are desired [13]. According to studies of Prassopolous spleen shapes are crecentric, rhomboid and triangular [14].

According to Sivanageswara Rao et al wedge shaped (40\%), Triangular shaped (32\%), Oval shaped (8\%) and tetrahedral shaped (20\%) [15].

In present study tetrahedral shaped spleens were more (55.4\%) than previous studies. Triangular (14.86\%) and wedge shaped (29.74\%) were less than previous studies. Oval and irregular shaped spleens were not found In present study, those shapes were present in previous studies.

According to Malawatkar the dimensions of the spleen are $1.4 \mathrm{~cm} \times 3.5 \mathrm{~cm} \times 7 \mathrm{~cm}[21] \mathrm{Her}$ ald Ellis discovered odd numbers related to dimensions of the spleen 1inches thickness, 3 inches width, 5 inches length, 7 ounces weight, related to $9^{\text {th }}$ to $11^{\text {th }}$ ribs. According to Sir Alfred Cushier the normal dimensions of the spleen are $3 \mathrm{~cm} \times 9 \mathrm{~cm} \times 13 \mathrm{~cm}$ [22].

Table 7: Comparison of shapes of spleen between previous studies and present study.

\begin{tabular}{|l|c|c|c|c|c|}
\hline \multirow{2}{*}{\multicolumn{1}{|c|}{ Previous studies }} & \multicolumn{5}{c|}{ Shape of the spleen } \\
\cline { 2 - 6 } & Wedge & Triangular & Tetrahedral & Oval & Irregular \\
\hline Rao et al. [16] & $40 \%$ & $32 \%$ & $20 \%$ & $8 \%$ & - \\
\hline Hollineshead [17] & $44 \%$ & $42 \%$ & $14 \%$ & - & - \\
\hline Chaware et al [18] & $61.26 \%$ & $12.61 \%$ & $21.62 \%$ & $3.60 \%$ & $0.90 \%$ \\
\hline Chaudhari ML [19] & $33.87 \%$ & $19.35 \%$ & $32.25 \%$ & $8.06 \%$ & $6.45 \%$ \\
\hline M Sangeeta et al [20] & $33.90 \%$ & $33.90 \%$ & $15 \%$ & $9.40 \%$ & - \\
\hline Present study & $29.74 \%$ & $14.86 \%$ & $55.40 \%$ & - & - \\
\hline
\end{tabular}

Table 8: Comparison of lengths, breadths, widths, weights and volumes between previous studies and present study.

\begin{tabular}{|l|c|c|c|c|c|c|c|}
\hline \multirow{2}{*}{ Previous studies } & \multirow{2}{*}{ Length } & \multirow{2}{*}{ Breadth } & \multirow{2}{*}{ Width } & \multicolumn{2}{c|}{ Weight } & \multicolumn{2}{c|}{ Volume } \\
\cline { 6 - 9 } & & & & Average & Range & Average & Range \\
\hline Michels N A [23] & $11 \mathrm{~cm}$ & $7 \mathrm{~cm}$ & - & - & - & - & - \\
\hline Text book of Gray's Anatomy [1] & $12 \mathrm{~cm}$ & $7 \mathrm{~cm}$ & $3-4 \mathrm{~cm}$ & $150 \mathrm{gms}$ & $80 \mathrm{gms}$ to 300gms & - & - \\
\hline Chaudhari et al [19] & $9.59 \mathrm{~cm}$ & $6.59 \mathrm{~cm}$ & $4.54 \mathrm{~cm}$ & $150 \mathrm{gms}$ & $80 \mathrm{gms}$ to $350 \mathrm{gms}$ & - & - \\
\hline Chaware et al [18] & $9.66 \mathrm{~cm}$ & $6.22 \mathrm{~cm}$ & $3.06 \mathrm{~cm}$ & $145.76 \mathrm{gms}$ & $80 \mathrm{gms}$ to $300 \mathrm{gms}$ & - & - \\
\hline Sivanageswara Rao et al [15] & $10.15 \mathrm{~cm}$ & $8.30 \mathrm{~cm}$ & $3.96 \mathrm{~cm}$ & $138.4 \mathrm{gms}$ & $30 \mathrm{gms}$ to $300 \mathrm{gms}$ & - & - \\
\hline M Sangeeta et al [20] & $9.68 \mathrm{~cm}$ & $6.84 \mathrm{~cm}$ & $3.61 \mathrm{~cm}$ & - & $53 \mathrm{gms}$ to $444 \mathrm{gms}$ & - & - \\
\hline Present study & $9.78 \mathrm{~cm}$ & $5.96 \mathrm{~cm}$ & $4.95 \mathrm{~cm}$ & $141.77 \mathrm{gms}$ & $100 \mathrm{gms}$ to $200 \mathrm{gms}$ & $140.45 \mathrm{~cm} 3$ & $55.57 \mathrm{~cm} 3-363.77 \mathrm{~cm} 3$ \\
\hline
\end{tabular}

Socioeconomic status, feeding habits, geographical conditions and genetic factors are different in western countries and India that is why values in present study were slightly lower than previous studies. Morphometric volume of spleen was not considered by previous 
studies. Previous studies on volume of spleen were based on ultrasonogrphy image of spleen, computed tomography image of spleen and Magnetic resonance imaging image of spleen. In present study morphometric volume of spleen is considered. Volume of spleen in present study was varied between $55.57 \mathrm{~cm} 3$ to $363.77 \mathrm{~cm} 3$ and average volume was $140.45 \mathrm{~cm} 3$.

\section{CONCLUSION}

In present study includes shape, number of notches, length, width, thickness, weight and volume of the spleen. Morphometric Volume of spleen is most important factor in diagnosis of various disorders of spleen, which was not considered by previous studies. Morphometric analysis in present study will be helpful for surgeons, and physicians in diagnosis and treatment of different disorders of spleen

\section{Conflicts of Interests: None}

\section{REFERENCES}

[1]. Standring S: Gray's Anatomy: The Anatomical Basis of the Clinical Practice, 40th edition. Edinburg: Elsevier Churchill Livingstone, 2006;1191-44.

[2]. Ross M H. Histology - A text book and Atlas 3rd edition. Lippincott Wiliams \& Wilkins. 1999:34953.

[3]. Robert A Foctitas Jr. Nano medicine, volume III A; Biocompactibility, Caders Biosciences, George Town. ISBN-10: 1570596808. Edition: 1. June 1999.

[4]. Adman F E Park, Rodnick Mckimij. Schwartz's Principles of Surgery McGraw -Hill. 2005;292.

[5]. Vasalius. A catalog of the H.Winnet Orr Historical collection. American college of surgeons; Chicago 1960. Library of congress catalogue. Card number 60-11348

[6]. Douglas L Fraker. Surgery - Scientific principles and practice 3rd edition. Philadelphia, Pa; London : Lippincott Williams \& Wilkins 2001;1236-59.

[7]. Bruce M. Carlson. Human embryology and developmental biology, $3^{\text {rd }}$ edition: Elsevier Mosby, 2004;357.

[8]. Albarzanji AJ, Penny SR, Lemery J. Pathology of spleen. Journal of Clinical Pathalogy. 1976:29;657-679.
[9]. G.J.Romanes, The abdominal cavity, Cunningham manual of practical anatomy, fifteenth edition, New yourk,Oxford university press,2008;126-127.

[10]. Joanne M . Willey, Linda M .Sherwood, Christopher J .Woolverton . Prescott's Microbiology, $9^{\text {th }}$ edition : MacGraw Hill Education 2013 Aug;742.

[11]. John Macleod. Macleod's clinical examination, $12^{\text {th }}$ edition: Churchill Livingstone 2009 June;202.

[12]. Rezai P, Tochetto SM, Galizaia MS, Yaghmai V. Spleenic volume model constructed from standardized one-dimensional MDCT measurements. American Journal of Roentgenol. 2011 Feb ;196(2):36772.

[13]. Sir Afred Cushieri, Robert JC, Steel. Essentials of Surgical Practice, Butterworth-Heinemann Limited, 4th edition. 2000;454-75.

[14]. Prassopoulos P, Daskalogiannaki M, Raissaki A, Hatjidakis, Gourtsoyiannis. Determination of normal spenic volume on computed tomography in relation to age, genderand habitus. Europian Radiology.1997;7:246-48.

[15]. Sivanageswara Rao , Sundara Setty , Raja Sekhar Katikireddy. Morphometric study of spleen. International journal of biological and medical research. 2013;4(3):3464-3468.

[16]. Rao S, Setty S, Katikireddi RS. Morphometric Study of Human Spleen. Int J Biol Med Res. 2013;4(3):34643468.

[17]. Hollinshead WH. Anatomy for Surgeons. 3rd ed. vol2. New York: Harper and Row, 1982;436-45.

[18]. Charware PN, Belsare SM, Kulkarni YR, Pandit SV, Ughade JM. The Morphological Variations of the Human Spleen. Journal of Clinical and Diagnostic Research. 2012 April;6(2):159-162.

[19]. Chaudhari ML, Maheria PB, Lakhani C, Menezes VR. Morphological variation of human spleen its clinical significance. International journal of medical research and review. 2014;2(1):16-20.

[20]. M Sangeeta, K L Varalakshimi, B N Sahana Cadaveric study of morphometry of spleen. Journal of medical sciences and health 2015;01(03):14-17.

[21]. Malwatkar SG. Integrated text book of Anatomy. Oxford university press. ISBN 0195648722. 1999;10010.

[22]. Herald Ellis. Clinical Anatomy. Blackwell publications. 2002;110-13.

[23]. Michels NA. The variational anatomy of the spleen and the splenic artery. American Journal of Anatomy 1942; 70:21-72.

How to cite this article:

Ganesh Trimbak Waghmode, Satishkumar Sukhanand Porwal, Pavankumar Bharat Shinde, Uma Trimbak Waghmode. MORPHOLOGICAL ANALYSIS OF VARIATIONS OF SPLEEN. Int J Anat Res 2017;5(2.1):3693-3697. DOI: 10.16965/ijar.2017.100 